\title{
Capital - Energy Substitution: Does Energy Sources Matter for the Elasticity of Substitution? An Empirical Investigation for OECD
}

\section{Countries*}

\author{
Ömer Faruk Altunç ${ }^{1} \oplus$, Abdulmecit Yıldııım 1 ๑
}

\begin{abstract}
Energy and other factors of production are the primary inputs in the context of sustainable economic growth. This makes energy relatively strategic in the development stage and in the energy importers economies. In this study, the effect of elasticity of substitution on economic growth is investigated for 31 OECD countries over the period from 1990-2014. Although the effect of elasticity of substitution between capital and aggregate energy consumption on economic growth has been examined in many studies, the issue of how this effect changes between the different sources of energy has not been adequately addressed. The research is aimed at contributing to the related literature in this regard. The effect of elasticity of substitution between capital and different energy sources on economic growth is examined within the neoclassical Solow-Swan Growth model. In this model, technology is defined by a variable elasticity of substitution (VES) production function. The empirical model is estimated by the non-linear least squares (NLLS) method. The results show that oil and primary energy consumption are substitutes; natural gas, coal, and hydroelectricity consumption are the complement in the final production of output.
\end{abstract}

JEL Code: D24, C13, Q43

Keywords

Production Inputs, Energy, Elasticity of Substitution, VES Production Function

1 Ömer Faruk Altunç (Prof. Dr.), Muş Alparslan University, Faculty of Economics, Department of Economic History, Muş, Turkey. E-posta: o.altunc@alparslan.edu.tr ORCID: 0000-0002-1563-7990

Corresponding author: Abdulmecit Yıldırım (Assist. Prof. Dr.), Muş Alparslan University, Departmen of Economics, Department of Economic History, Muş, Turkey. E-mail: a.yildirim@alparslan.edu.tr ORCID: 0000-0002-6228-6601

* This article is a revised version of the paper presented at the 2018 ICE-TEA, International Economic Conference, Antalya/ Turkey.

To cite this article: Altunc, O. F., \& Yildirim, A. (2020). Capital - Energy Substitution: Does Energy Sources Matter for the Elasticity of Substitution? An Empirical Investigation for OECD Countries. SiYASAL: Journal of Political Sciences, 29(2), 367378. http://doi.org/10.26650/siyasal.2020.29.2.0087 


\section{Introduction}

Theoretical and empirical studies show that one of the most significant elements of growth is the energy used to generate physical capital, which is typically needed for development. As physical capital grows, the amount of energy required increases (Stern 2011; Acemoğlu 2009; van Zon and Yetkiner 2003). This indicates that there is a complementarity between capital and energy in contrast to studies showing that the two factors are the substitute in the final production of output. The elasticity of substitution (henceforth ES) between capital and energy is one of the long-debated issues in the energy economy literature. In view of a supply-side approach, the adoption of energy-saving technologies is represented by substituting capital for energy, and ES between capital and energy is important for policies aimed at reducing energy consumption and reducing emission-derived pollution. ES is an indicator of the degree to which one input can be substituted by the other in an economic system. The high level of elasticity of substitution indicates the ease of substitution of the inputs.

The coefficient of the ES parameter indicates whether there is a substitution or complementary relationship between inputs (Costantini and Paglialunga 2014). The substitution of energy resources with other factors of production is important to avoid an energy crisis and to meet goals towards reducing fossil fuel while sustaining economic growth. The long-run growth potential of the economy depends largely on the degree of elasticity of substitution between capital and energy (Chichilnisky and Heal 1983). In the context of ES, technological progress plays an important role, which is highlighted in most theoretical studies. Technological development influences the relationship between physical capital and required energy in three different ways. Firstly, technological improvements gives the ability to create a new generation of physical capital that needs less energy. Secondly, technology helps to generate more energy with the same inputs and to create new technologies for energy production that make more efficient use of energy resources, such as fossil fuels. Finally, technological improvements enables the discovery of new energy sources such as water, sun, and wind. However, according to the International Energy Agency, approximately $80 \%$ of the world's energy demand is still met by the consumption of non-renewable fossil fuels.

Empirical studies provide contradictory evidence on the relationship between capital and energy, in terms of both time and space. While capital and energy are found complementary in some sectors and regions, it is reported that they can be easily substituted in others. One reason for these heterogeneous results is that the ease of substitution between capital and energy increases with technological advances. Following the oil crises in the 1970s, economists and policymakers attached great importance to the performance of energysaving technologies. Analysis of energy-saving technologies can be represented by capitalenergy substitution. The concept of elasticity of substitution developed by Hicks is used to measure the degree of the substitutability between the production inputs. ES shows how a change in factor prices affects the income distribution between the factors. It also measures whether a factor can be easily substituted for the other. This measurement is only valid for the two-variable case. Allen (1937) generalized Hicks elasticity of substitution for cases with multiple variables. The main literature on capital-energy substitution is built on understanding the economic responses to the oil crises that emerged in the 1970s. The 
aim was to demonstrate how oil can be substituted by coal, gas, and electricity to reveal the need to develop more efficient energy production methods.

Early studies were based on the substitution of fuels at given capacities in the electricity sector, and the long-run substitution predicted from the cross-country data for the electricity sector and non-energy sectors (Pindyck 1979). The pioneering study of Berndt and Wood (1975) on factor substitution promoted a large number of empirical studies. In their study, Berndt and Wood (1975), investigated the possibilities of substitution between energy and non-energy inputs using time series data over the period from 1947-1971. Four inputs namely, capital, labor, energy, and intermediate inputs were used in the study in which the Translog cost function was used. It was assumed that there would be a constant return to scale production function with the Hicks-neutral technological progress. Allen elasticity of substitution (AES) was used in the calculations. The findings of the study reported that the substitution relationship between energy and non-energy inputs was technically present but limited. Moreover, it concluded that energy and labor were substitutes while energy and capital were complements. Griffin and Gregory (1976) criticized the results of the study conducted by Berndt and Wood (1975) in terms of the time series data used in the study. Griffin and Gregory (1976) argued that the time series data only responded to changes in prices in the short run, and therefore capital and energy were complements in the short-run. However, energy and capital were expected to be substitutes as new equipment was used to achieve high-energy efficiency in the long run. The Pindyck (1979) analyses a pooled time series data over the period from 1963-1973 for a crosssection of countries and found that energy and capital were substitutes. Ozalatay et al. (1979) concluded that energy and capital were substitutes for the United States economy using data over the 1963-1974 period. In another study conducted specifically for 10 manufacturing industry sub-sectors in the American economy, Field and Grebenstein (1980) found that there was a complementarity between energy and physical capital for four sub-sectors and no significant result was found for the remaining six sub-sectors.

Blackorby and Russel (1989) reported that AES was not a good measurement tool. They claimed that the Morishima Elasticity of Substitution (MES) was a better alternative than AES. MES measures the effect of price changes despite the change in the factor proportions. Thomson and Taylor (1995) re-evaluated eight studies and concluded that energy and capital were complements and re-determined the results using MES. The findings showed that energy and capital were substitutes for all studies. Nguyen and Strietwiesser (1997), in their study based on microdata used for the American economy, estimated ES between energy and capital according to both AES and MES. Energy and capital were found to be weak substitutes when using AES to calculate ES. On the other hand, MES results revealed a strong substitution relationship between energy and capital. Apostolakis (1990) stated that capital and energy were complements in the studies based on time series data, and two inputs were observed to be substitutes in the studies based on the cross-sectional data of countries or regions. According to Apostolakis (1990), these different results were due to the fact that the time series reflected the short-run relationships, while the cross-sectional data analyzes captured the long-run effects. The problem such as differences in data set, functional forms used, elasticity (gross and net elasticity), and measurement of capital were the other reasons. Griffin and Gregory (1976) 
and Apostolakis (1990) reported that the cross-sectional data captured long-run response to price changes, and therefore estimation results revealed a substitution relationship between the two inputs. On the contrary, since time series data reflects short-run responses to price changes, it may lead to a complementary relationship between two inputs.

In a more recent analysis using data at the industrial level, Tovar and Iglesias (2013) estimated a five-factor model in which capital was divided into physical and labor capital. The authors found that in the long-run energy was complementary for both forms of resources, and in the short-run this relationship was not important. Kim and Heo (2013) found different values for ES between fossil fuels and physical capital, and between electricity and physical capital. In this study, they investigated ES between different energy sources and capital by using a translog cost function. Empirical results showed that electricity and capital were substitutes, while fuel tended to complement for capital in most countries. In addition, it was concluded that the difference in energy sources may significantly affect ES between energy and capital. Haller and Hyland (2014) used the trans-log cost function to model production in the Irish manufacturing sector over the period from 1991-2009. In the study, ES between capital, labor, material, and energy was calculated. The results revealed that energy and capital were substitutes in the production of output. Lazkano and Pham (2016) investigated ES between energy and capital by using data from 108 countries over the period 1971-2011. They extended their analysis for different country groups based on various classifications. Empirical results provided evidence that there was a variable elasticity of substation between capital and energy. Moreover, the results indicated that policies that increased the rate of capitalenergy substitution would support long-run economic growth. Deininger et al. (2018) examined the factor substitution among capital, labor, energy, and material in the Swiss manufacturing industry over the period from 1997-2008 by dividing the firms into three subcategories according to energy intensity. The results of the study showed that, except for energy-intensive firms, there was a substitution relationship between capital, labor, energy, and materials. However, in the case of the energy-intensive firm, it found that there was a complementarity relationship between energy and capital.

Knowing the degree of elasticity of substitution between energy and other production factors can be important for policymakers. Besides being able to reduce the impact of possible energy crises, it is also possible to reduce the use of fossil fuels for sustainable growth. To achieve such policies ES plays a crucial role. In addition, countries that are more sensitive to environmental pollution have a stronger motivation to reduce fossil fuel energy consumption. Thus, capital-energy substitution can affect countries with such sensitivities.

The rest of the paper is organized as follows. Section 2 presents the model and estimation methodology. Data set and descriptive statistics are discussed in section 3 . Section 4 analyses the results and section 5 draws the conclusion and evaluation.

\section{Model and Estimation Method}

The production function including physical capital (P), labor (L), Energy (E) as production inputs and consisting of two stages can be defined by equations (1) and (2). The variables Y, P, L, and E are time-dependent variables, but for simplicity, we omit the 
time subscript from the equations. In this study, since the primary aim is to investigate ES between different energy sources and capital, equation (1) is defined as a Cobb-Douglas production function, which has the standard properties of production functions. In equation (2), by following Revenkar (1997), we defined a VES type production function, which allows a variable elasticity of substitution between capital and different energy sources.

$$
\begin{aligned}
& Y=F(P, L)(1) \\
& P=X(K, E)(2)
\end{aligned}
$$

The production functions that are assumed to have constant returns to scale can be written more clearly as in equation (3) and (4). While equation (3) shows the relationship between output, physical capital, and labor, equation (4) is a VES type production function that shows how physical capital accumulates in the model. While $a_{1}$ reflects the role of physical capital $(\mathrm{P})$ in the production process, $a_{2}$ reflects the importance of capital $(\mathrm{K})$ relative to energy $(\mathrm{E})$ in the production of total physical capital $(\mathrm{P}) . b$ is a parameter affecting the aggregate degree of substitutability between capital and energy.

$$
\begin{aligned}
& Y=A P^{\alpha_{1}} L^{1-\alpha_{1}}(3) \\
& P=K^{\alpha_{2}}\left(E+b \alpha_{2} K\right)^{1-\alpha_{2}}
\end{aligned}
$$

Substituting equation (4) into equation (3), we obtain the general nested production function as in equation (5).

$$
\begin{aligned}
& Y=A\left(K^{\alpha_{2}}\left(E+b \alpha_{2} K\right)^{1-\alpha_{2}}\right)^{\alpha_{1}} L^{1-\alpha_{1}}(5) \\
& \sigma(K, E)=\frac{\partial \ln (K / E)}{\partial \ln \left(M P_{K} / M P_{E}\right)}
\end{aligned}
$$

Equation (7) and (8) show the marginal physical products of capital and energy. Using the formula in equation (6), which refers to ES between capital and energy, ES between capital and energy for a VES type production function can be defined as in equation (9) ${ }^{1}$.

$$
\begin{aligned}
& M P_{K}=\frac{\partial Y}{\partial K}=\frac{A L^{1-\alpha_{1}} \alpha_{1} \alpha_{2}(E+b K)\left(K^{\alpha_{2}}\left(E+b \alpha_{2} K\right)^{1-\alpha_{2}}\right)^{\alpha_{1}}}{K\left(E+b \alpha_{2} K\right)}(7) \\
& M P_{E}=\frac{\partial Y}{\partial E}=\frac{A L^{1-\alpha_{1}} \alpha_{1}\left(1-\alpha_{2}\right)\left(K^{\alpha_{2}}\left(E+b \alpha_{2} K\right)^{1-\alpha_{2}}\right)^{\alpha_{1}}}{E+b \alpha_{2} K}(8) \\
& \sigma(K, E)=1+b\left(\frac{K}{E}\right)(9)
\end{aligned}
$$

Equation (9) shows that ES between capital and energy may vary depending on the capital energy ratio. If ES parameter is equal to zero $(b=0)$, ES between capital and energy is constant. In other words, when $b=0$, the production function returns to the standard Cobb-Douglas production function. On the other hand, if $b<0$, ES is less than 1 and, there will be a complementary feature between capital and energy. If $b>0$, ES is greater than 1 , which indicates that capital and energy are substitutes in the final production of output. In short, in the case of $b \neq 0$, ES varies depending on the capital-energy ratio.

Log-linearizing the production function stated in equation (5) gives the main equation (10) to be empirically estimated. The production function and the estimation equation

1 Derivation of the elasticity of substitution is available upon request. 
derived from this function is a non-linear equation. Therefore, a non-linear estimator is used. Although the logarithm of the equation is taken, this transformation does not make the equation linear. Since the model is not in linear in parameters, NLLS is an appropriate estimation method. Chumacero (2006) states that one of the desirable properties of the NLLS estimation is that one does not need to know the precise nature of heteroskedasticity and/or autocorrelation. Once this equation is estimated for each energy sources, the obtained elasticity of substitution parameter $(b)$ and equation (9) is used to measure ES between capital and energy.

$$
\ln Y=\ln A+\alpha_{1} \alpha_{2} \ln K+\alpha_{1}\left(1-\alpha_{2}\right) \ln \left(E+b \alpha_{2} K\right)+\left(1-\alpha_{1}\right) \ln L+\epsilon \text { (10) }
$$

Following Tallman and Wang (1994), and Duffy and Papageorgiou (2000), we construct another series for labor input that is adjusted for human capital. Equation (10) is estimated by using raw labor (L) and human capital adjusted labor (HL) as a measure of labor input. In any country $i$, the human capital in time $t$ can be expressed as $H_{i t}=E_{i t}$. Here, $E_{i t}$ refers to average yeathe $\mathrm{r}$ of schooling for each country. Thus, human capital adjusted labor can be expressed as in equation (11).

$$
H L_{i t}=H_{i t} * L_{i t}=E_{i t} * L_{i t}(11)
$$

VES production function is estimated using both raw labor (L) and human capital adjusted labor (HL). Equation (10) is estimated by non-linear least squares (NLLS) using data on total factor productivity, capital stock, energy, real GDP and either raw labor (L) or human capital adjusted labor (HL). In this model, total factor productivity is used as a proxy to take into account the differences in technological development among countries.

\section{Data Set and Descriptive Statistics}

The estimation of VES production function in equation (5) requires data on output (Y), total factor productivity (TFP), capital stock (K), labor (L) and energy (E). The data set covers 25 years (1990-2014) and 31 OECD countries ${ }^{2}$. A regular and credible data set on energy types is only obtained for OECD countries. Therefore, the study has been limited to OECD countries. This constraint is the main limitation of the study.

Total output, capital stock, total factor productivity, labor, and human capital data were obtained from the Penn World Table (Feenstra et al., 2015) data set. Data on different energy sources were obtained from the BP Statistical Review of World Energy (2017). The countries and the period were selected to maximize the number of observations for a balanced panel data set. Table 1 presents the variables and data sources. Descriptive statistics are presented in Table 2. The two-way correlation coefficients between variables are presented in Appendix-1. These statistics subsequent estimations are carried out by Stata14.

2 The series in pwt9 contain data until 2014. 
Table 1

Variables and Data Sources

\begin{tabular}{|l|c|c|c|}
\hline Variables & Indicators & Unit of Measurement & Sources \\
\hline Real GDP & Y & $\begin{array}{c}\text { Constant national prices (in millions of } \\
\text { 2005 US Dollars) }\end{array}$ & $\begin{array}{c}\text { Penn Table (version } \\
\text { PWT 9) }\end{array}$ \\
\hline Capital Stock & K & $\begin{array}{c}\text { Constant national prices (in millions of } \\
\text { 2005 US Dollars) }\end{array}$ & $\begin{array}{c}\text { Penn Table (version } \\
\text { PWT 9) }\end{array}$ \\
\hline Population & L & Million & $\begin{array}{c}\text { Penn Table (version } \\
\text { PWT 9) }\end{array}$ \\
\hline Human Capital Index & H & Greater than 1 & $\begin{array}{c}\text { Penn Table (version } \\
\text { PWT 9) }\end{array}$ \\
\hline TFP & A & TFP in terms of PPP (USA 1) & $\begin{array}{c}\text { Penn Table (version } \\
\text { PWT 9 }\end{array}$ \\
\hline Coal & E & mtoe & BP Statistics \\
\hline Gas & E & mtoe & BP Statistics \\
\hline Hydroelectric & E & mtoe & BP Statistics \\
\hline Oil & E & Million Tonnes & BP Statistics \\
\hline $\begin{array}{l}\text { Primary Energy } \\
\text { Sources }\end{array}$ & mtoe & BP Statistics \\
\hline
\end{tabular}

Note: The human capital index is in terms of average years of schooling, and the return to education per person. PPP and TFP stand for purchasing power parity and total factor productivity respectively. mtoe is million-ton oil equivalent. Penn World Table data is from Feenstra, Inklaar and Timmer 2015.

Table 2

Descriptive Statistics

\begin{tabular}{|l|c|c|c|c|}
\hline & $(\mathbf{1})$ & $\mathbf{( 2 )}$ & $\mathbf{( 3 )}$ & (4) \\
\hline Variables & Mean & sd & Min & Max \\
\hline Real GDP & 1232166 & 2407871 & 29529.18 & $1.65 \mathrm{e}+07$ \\
\hline Capital Stock & 3901613 & 7490288 & 77120.27 & $5.28 \mathrm{e}+07$ \\
\hline Population & 37.7560 & 55.6241 & 2.9168 & 319.4486 \\
\hline Human Capital Index & 3.1116 & 0.4114 & 1.8024 & 3.7343 \\
\hline TFP & 0.7901 & 0.1409 & 0.3987 & 1.1211 \\
\hline Coal & 35.51766 & 92.86734 & 0.0838 & 574.4632 \\
\hline Gas & 39.28934 & 103.0337 & 0.0073142 & 690.0358 \\
\hline Hydroelectric & 9.500382 & 17.57951 & 0.0006788 & 88.67717 \\
\hline Oil & 68.89465 & 151.3492 & 2.372 & 938.3952 \\
\hline Primary Energy Sources & 171.1436 & 391.0339 & 5.187898 & 2370.248 \\
\hline
\end{tabular}

Note: GDP and TFP stand for gross domestic product and total factor productivity, respectively.

Figure 1 shows the primary energy consumption ${ }^{3}$ in OECD countries between 1990 and 2014, while Figure 2 shows the final energy consumption from 1990 to 2014 on the basis of different energy sources such as oil, natural gas, hydroelectric and coal. In general, primary energy consumption in OECD countries had shown an upward trend in the 1990-2014 period. Although a decrease in primary energy consumption was observed following the global crisis in 2008, it tended to recover gradually in the following years. A similar trend was observed when considering different energy sources. Considering the energy sources used in this study, natural gas had the fastest increase in consumption among all energy sources.

3 Just commercial solid fuels, i.e. bituminous coal and anthracite (hard coal), lignite and brown (subbituminous) coal, and other industrial solids. 


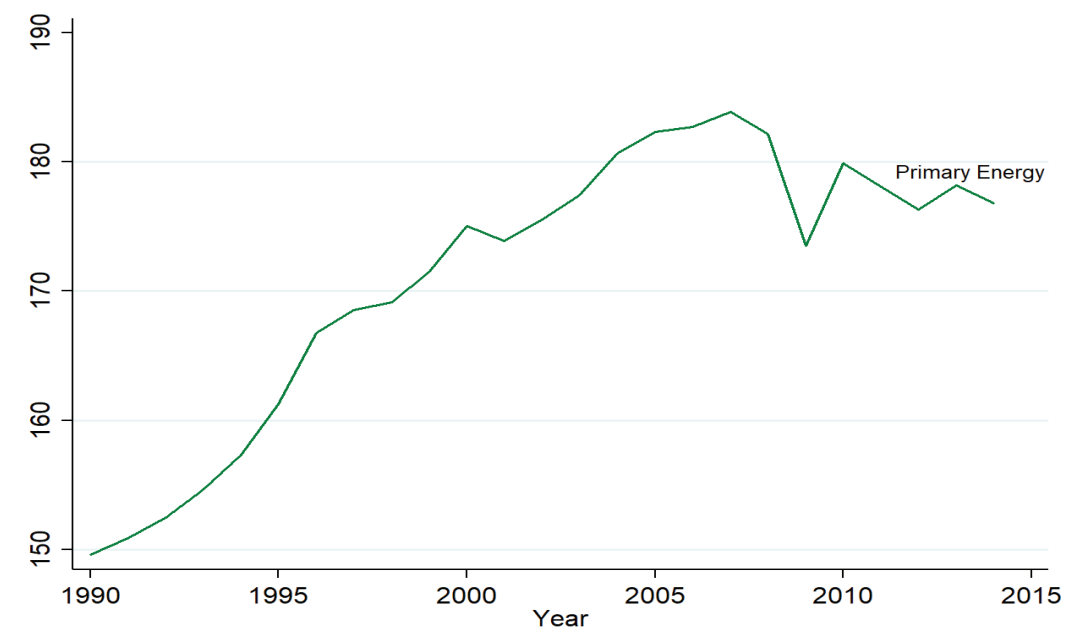

Figure 1. Mean of Primary Energy Consumption for OECD Countries, (1990-2014, mtoe)

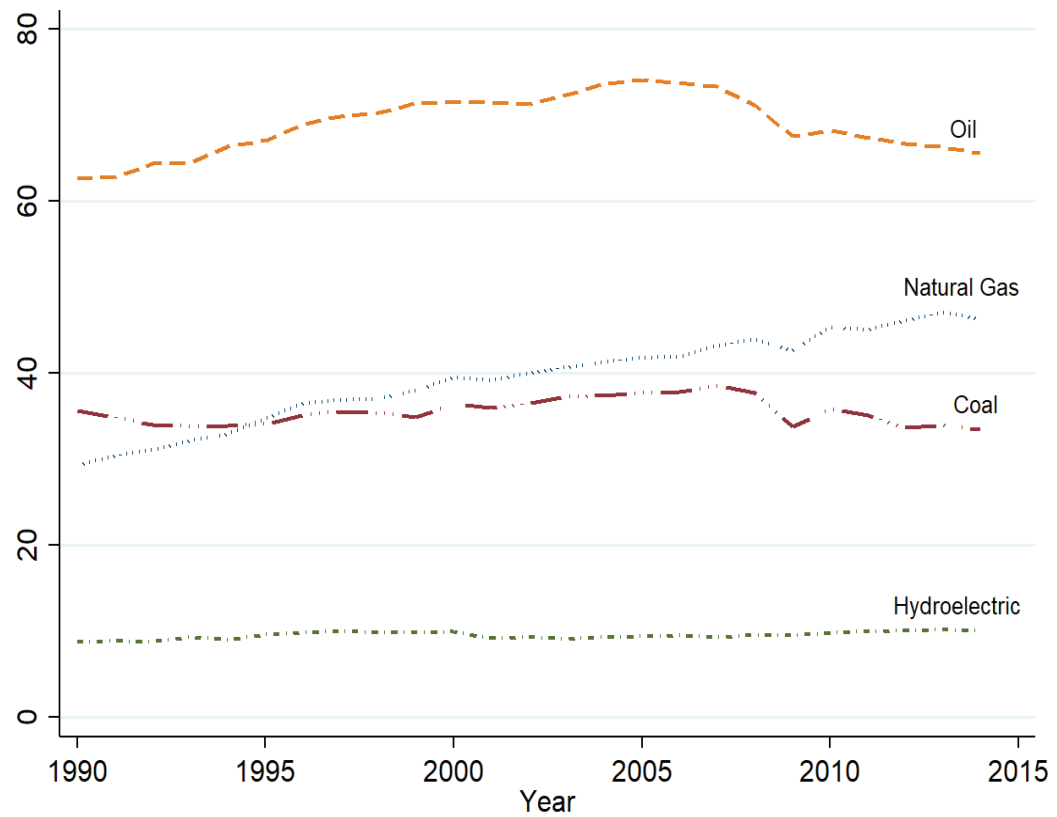

Figure 2. Mean of Energy Consumption for OECD Countries, (1990-2014, mtoe) 


\section{Empirical Results}

This section presents the empirical results of equation (10). In addition to the basic variables used for the estimation of equation 10, two dummy variables were added to the model. To consider the level of development among countries, a dummy variable was added to the model for countries which were not included in the advanced economies category according to the IMF country classification. In addition, as presented in Figure 1 and Figure 2, there was a trend shift in energy consumption after 2008. To consider the shift in energy consumption, time fixed effect dummy variable was added to the model. Following the inclusion of dummy variables, the empirical equation can be written as follows:

$\ln Y_{i t}=\ln A_{i t}+\alpha_{1} \alpha_{2} \ln K_{i t}+\alpha_{1}\left(1-\alpha_{2}\right) \ln \left(E_{i t}+b \alpha_{2} K_{i t}\right)+\left(1-\alpha_{1}\right) \ln L_{i t}+\theta_{i t}+\delta_{i t}+\epsilon_{i t}$

Here, the dummy variables $\theta_{i t}$ and $\delta_{i t}$ refer to the time fixed effect and development level of countries, respectively. We used the total factor productivity as an indicator of the technological progress of the countries. Therefore, empirical estimates will be more sensitive to changes in total factor productivity of countries.

Table 3 presents the non-linear regression results of equation (12). The upper panel of Table 3 reports the results for raw labor (L), and the lower panel reports the results for skilled labor (HL). The coefficient $b$, which is the determinant of ES in the empirical results, in which the raw labor force is used, is statistically significant for the natural gas, oil and primary energy sources, and statistically insignificant for coal and hydroelectric. Similar estimates were obtained, except for natural gas energy type, in the estimates using human capital adjusted labor in place of the labor force. Therefore, the initial findings provide evidence that there is a non-constant elasticity of substitution between oil and primary energy sources, and capital.

In cases when ES parameter (b) is statistically significant, it takes a negative value (see columns 2, 4 and 5 in the upper panel; columns 4 and 5 in the lower panel). The negative value of ES parameter (b) means that ES between energy sources and capital is smaller than one ${ }^{4}$. Therefore, capital and energy present a complementary feature in the final production of output. The smaller the ES parameter, the greater the complementarity between energy and capital.

Table 3

Non-linear Regression Estimates of VES Production Function

\begin{tabular}{|c|c|c|c|c|c|}
\hline \multicolumn{6}{|c|}{ Energy Sources } \\
\hline \multirow{2}{*}{ Parameters } & (1) & (2) & (3) & (4) & (5) \\
\hline & Coal & Natural Gas & Hydroelectric & Oil & Primary Energy Sources \\
\hline \multicolumn{6}{|c|}{ Raw Labor(L) } \\
\hline$a_{1}$ & $\begin{array}{c}0.9886^{* * * *} \\
(0.0347)\end{array}$ & $\begin{array}{c}0.8533 * * * \\
(0.0160)\end{array}$ & $\begin{array}{c}0.9299 * * * \\
(0.0288)\end{array}$ & $\begin{array}{c}1.1630 * * * \\
(0.0296)\end{array}$ & $\begin{array}{c}1.1972 * * * \\
(0.0277)\end{array}$ \\
\hline$a_{2}$ & $\begin{array}{c}0.8866^{* * *} \\
(0.0319)\end{array}$ & $\begin{array}{c}1.0212 * * * \\
(0.0180)\end{array}$ & $\begin{array}{c}0.9422 * * * \\
(0.0308)\end{array}$ & $\begin{array}{c}0.7529 * * * \\
(0.0191)\end{array}$ & $\begin{array}{c}0.7100 * * * \\
(0.0184)\end{array}$ \\
\hline
\end{tabular}

4 Remark: the elasticity of substitution for VES production function is $\sigma(K, E)=1+b\left({ }^{K} / E\right)$ 


\begin{tabular}{|c|c|c|c|c|c|}
\hline$b$ & $\begin{array}{c}1.17 \mathrm{e}-06 \\
(1.59 \mathrm{e}-06)\end{array}$ & $\begin{array}{c}-1.04 \mathrm{e}-08 * * \\
(4.67 \mathrm{e}-09)\end{array}$ & $\begin{array}{c}2.07 \mathrm{e}-06 \\
(3.83 \mathrm{e}-06)\end{array}$ & $\begin{array}{c}-6.16 \mathrm{e}-06^{* * *} \\
(1.78 \mathrm{e}-07)\end{array}$ & $\begin{array}{c}-1.72 \mathrm{e}-05 * * * \\
(4.58 \mathrm{e}-07)\end{array}$ \\
\hline \multicolumn{6}{|c|}{ Human Capital Adjusted Labor (HL) } \\
\hline$a_{1}$ & $\begin{array}{c}0.9565^{* * * *} \\
(0.0404)\end{array}$ & $\begin{array}{c}0.8104 * * * \\
(0.0184)\end{array}$ & $\begin{array}{c}0.8748 * * * \\
(0.0117)\end{array}$ & $\begin{array}{c}1.1406 * * * \\
(0.0322)\end{array}$ & $\begin{array}{c}1.2457 * * * \\
(0.0347)\end{array}$ \\
\hline$a_{2}$ & $\begin{array}{c}0.9112 * * * \\
(0.0348)\end{array}$ & $\begin{array}{c}1.0396 * * * \\
(0.0200)\end{array}$ & $\begin{array}{c}0.9861 * * * \\
(0.0097)\end{array}$ & $\begin{array}{c}0.7793 * * * \\
(0.0191)\end{array}$ & $\begin{array}{c}0.6996 * * * \\
(0.0189)\end{array}$ \\
\hline$b$ & $\begin{array}{c}8.49 \mathrm{e}-07 \\
(1.67 \mathrm{e}-06)\end{array}$ & $\begin{array}{l}-1.00 \mathrm{e}-08 \\
(6.69 \mathrm{e}-09) \\
\end{array}$ & $\begin{array}{c}-2.20 \mathrm{e}-09 \\
(5.82 \mathrm{e}-09) \\
\end{array}$ & $\begin{array}{c}-5.99 \mathrm{e}-06 * * * \\
(1.51 \mathrm{e}-07)\end{array}$ & $\begin{array}{c}-1.74 \mathrm{e}-05 * * * \\
(4.67 \mathrm{e}-07)\end{array}$ \\
\hline $\mathrm{R}^{2}(\mathrm{~L})$ & 0.9984 & 0.9983 & 0.9983 & 0.9985 & 0.9986 \\
\hline $\mathrm{R}^{2}(\mathrm{HL})$ & 0.9984 & 0.9984 & 0.9984 & 0.9985 & 0.9986 \\
\hline $\mathrm{N}$ & 775 & 775 & 775 & 775 & 775 \\
\hline
\end{tabular}

Note: The terms in bracket are standard errors. $* * *, * *$ and $*$ indicate significance level of 1\%, 5\% and $10 \%$ respectively.

Although the calculated elasticity of substitution parameter for natural gas, oil, and primary energy sources is statistically significant, the very small value of $b$ requires to test whether it is different from zero or not. Therefore, the findings related to the $b=$ 0 null hypotheses is presented in Table 4 for all energy sources. The null hypothesis, $b=0$, cannot be rejected in all cases when ES parameter is statistically insignificant. Therefore, it can be asserted that there is a constant elasticity of substitution between coal, hydroelectricity, and capital. In addition, the null hypothesis $b=0$ is rejected for oil and primary energy sources in cases when raw labor (L) and the human capital adjusted labor (HL) are used in place of labor input. Therefore, it is concluded that ES between these two energy sources and the capital varies depending on time and capital energy ratio.

Table 4

Tests of Hypothesis

\begin{tabular}{|l|c|c|c|c|}
\hline \multirow{2}{*}{ Energy Sources } & Labor Input & \multicolumn{2}{|c|}{$\begin{array}{c}\mathbf{H}_{\mathbf{0}}: \mathbf{b}=\mathbf{0} \\
\mathbf{H}_{\mathbf{1}}: \mathbf{b} \neq \mathbf{0}\end{array}$} & \multicolumn{1}{c|}{$\boldsymbol{\sigma}$} \\
\hline \multirow{2}{*}{ Coal } & & F Statistics & p-value & \\
\hline \multirow{2}{*}{ Natural Gas } & Raw Labor: L & 0.54 & 0.4638 & CD-CES \\
\cline { 2 - 5 } & Adjusted Labor: HL & 0.26 & 0.6124 & CD-CES \\
\cline { 2 - 5 } & Raw Labor: L & 4.98 & 0.0256 & VES \\
\cline { 2 - 5 } Hydroelectric & Adjusted Labor: HL & 2.24 & 0.1344 & CD-CES \\
\hline \multirow{2}{*}{ Oil } & Raw Labor: L & 0.29 & 0.5884 & CD-CES \\
\cline { 2 - 5 } & Adjusted Labor: HL & 0.14 & 0.7052 & CD-CES \\
\hline \multirow{2}{*}{ Primary Energy Sources } & Raw Labor: L & 1197.94 & 0.0000 & VES \\
\cline { 2 - 5 } & Adjusted Labor: HL & 1568.40 & 0.0000 & VES \\
\cline { 2 - 5 } & Raw Labor: L & 1402.15 & 0.0000 & VES \\
\cline { 2 - 5 } & Adjusted Labor: HL & 1384.62 & 0.0000 & VES \\
\hline
\end{tabular}

\section{Conclusion and Evaluation}

In this study, the elasticity of the substitution between capital and various energy sources was examined within the framework of a nested VES production function. The parameters of the nested VES production function was estimated for 31 OECD countries 
using data on real GDP, capital stock, total factor productivity, labor (raw labor and human capital adjusted labor) and five different energy sources. The parameters were estimated via a non-linear estimation method using a panel data set covering the period of 19902014. The results of the study show that the ES parameter (b) is negative in cases when it is statistically significant. Thus, oil, natural gas (in the case of raw labor), and primary energy sources are the complements of capital stock in the final production of output. ES between these inputs indicates the VES feature and it varies depending on the capitalenergy ratio. There was no evidence that ES between capital and other energy sources (coal, natural gas (in the case of the human capital adjusted labor, and hydroelectricity) are variable. Therefore, ES between these energy sources and capital may be more appropriately examined with CES or Cobb-Douglas-type production functions, which have constant elasticity of substitution property.

There was no consensus in the literature regarding the elasticity of the substitution between capital and energy. The results of the studies on ES differ from country to country. More importantly, even studies on the same country obtained different results. The main reason for these inconsistent results is the theoretical and empirical model used and the time-period selected for the data set. Therefore, the calculated coefficient of ES should be carefully evaluated and treated with caution.

Although the aggregated set of data used in this study provided meaningful deductions about ES between capital and various energy sources, more precise results can be obtained using industry-level data. In this respect, the present study can be developed for further studies.

\begin{tabular}{|c|c|c|c|c|c|c|c|c|c|c|}
\hline - & $\begin{array}{l}\text { Real } \\
\text { GDP }\end{array}$ & $\begin{array}{l}\text { Capital } \\
\text { Stock }\end{array}$ & Population & $\begin{array}{c}\text { Human } \\
\text { Capital Index }\end{array}$ & TFP & Coal & $\begin{array}{c}\text { Natural } \\
\text { Gas }\end{array}$ & Hydroelectric & Oil & $\begin{array}{c}\text { Primary Energy } \\
\text { Sources }\end{array}$ \\
\hline Real GDP & 1.00 & & & & & & & & & \\
\hline Capital Stock & $.987^{*}$ & 1.00 & & & & & & & & \\
\hline Population & $.953 *$ & $.928 *$ & 1.00 & & & & & & & \\
\hline $\begin{array}{l}\text { Human Capital } \\
\text { Index }\end{array}$ & $.255^{*}$ & $.281^{*}$ & $.101^{*}$ & 1.00 & & & & & & \\
\hline TFP & $.314^{*}$ & $.286^{*}$ & $.266^{*}$ & -.055 & 1.00 & & & & & \\
\hline Coal & $.948 *$ & $.915^{*}$ & $.892 *$ & $.279^{*}$ & $.234^{*}$ & 1.00 & & & & \\
\hline Natural Gas & $.962 *$ & $.938 *$ & $.901 *$ & $.264^{*}$ & $.301 *$ & $.966^{*}$ & 1.00 & & & \\
\hline Hydroelectric & $.574^{*}$ & $.553 *$ & $.527^{*}$ & $.278^{*}$ & $284^{*}$ & $.556^{*}$ & $.632^{*}$ & 1.00 & & \\
\hline Oil & $.979 *$ & $.948 *$ & $.938 *$ & $.242^{*}$ & $.295^{*}$ & $.974 *$ & $.975^{*}$ & $.610^{*}$ & 1.00 & \\
\hline $\begin{array}{l}\text { Primary Energy } \\
\text { Sources }\end{array}$ & $.977^{*}$ & $.949 *$ & $.923 *$ & $.270^{*}$ & $.297^{*}$ & $.982 *$ & $.988 *$ & $.637^{*}$ & $.995^{*}$ & 1.00 \\
\hline
\end{tabular}

* Indicates $5 \%$ significance level.

Appendix-2. List of Countries

Australia, Austria, Belgium, Canada, Chile, Czech Republic, Denmark, Finland, France, Germany, Greece,

Hungary, Ireland, Israel, Italy, Japan, Lithuania, Mexico, Netherlands, New Zealand, Norway, Poland, Portugal,

Slovakia, South Korea, Spain, Sweden, Switzerland, Turkey, United Kingdom, United States

Peer-review: Externally peer-reviewed.

Conflict of Interest: The authors have no conflict of interest to declare.

Grant Support: The authors declared that this study has received no financial support. 


\section{References}

Acemoglu, D. (2009). Introduction to modern economic growth. Princeton University Press.

Apostolakis, B. E. (1990). Energy--capital substitutability/ complementarity: The dichotomy. Energy Economics, 12(1), 48-58. https://doi.org/10.1016/0140-9883(90)90007-3

Berndt, E. R., \& Wood, D. O. (1975). Technology, Prices, and the Derived Demand for Energy. The Review of Economics and Statistics, 57(3), 259-268.

Blackorby, C., \& Russell, R. R. (1989). Will the Real Elasticity of Substitution Please Stand Up? (A Comparison of the Allen/Uzawa and Morishima Elasticities). American Economic Review, 79(4), 882-888.

Chichilnisky, G. (1993). Energy-Capital Substitution: A General Equilibrium Analysis. SSRN Electronic Journal. https://doi.org/10.2139/ssrn.1374615

Chumacero R. A. (2006). "Lecture notes on econometrics", manuscript, University of Chile.

Costantini, V., \& Paglialunga, E. (2014). Elasticity of substitution in capital-energy relationships: how central is a sector-based panel estimation approach? (SEEDS Working Papers No. 1314). SEEDS, Sustainability Environmental Economics and Dynamics Studies. https://ideas.repec.org/p/srt/wpaper/1314.html

Deininger, S. M., Mohler, L., \& Mueller, D. (2018). Factor substitution in Swiss manufacturing: empirical evidence using micro panel data. Swiss J Economics Statistics, 154(6). doi:10.1186/s41937-017-0016-5

Feenstra, R. C., Inklaar, R., \& Timmer, M. P. (2015). The Next Generation of the Penn World Table. American Economic Review, 105(10), 3150-3182. doi: 10.1257/aer.20130954

Griffin, J. M., \& Gregory, P. R. (1976). An Intercountry Translog Model of Energy Substitution Responses. American Economic Review, 66(5), 845-857.

Haller, S. A., \& Hyland, M. (2014). Capital-energy substitution: Evidence from a panel of Irish manufacturing firms. Energy Economics, 45, 501-510.

Kim, J., \& Heo, E. (2013). Asymmetric substitutability between energy and capital: Evidence from the manufacturing sectors in 10 OECD countries. Energy Economics, 40, 81-89.

Lazkano, I., \& Pham, L. (2016). Can Capital-Energy Substitution Foster Economic Growth? Land Economics, 92(3), 491-514. doi:10.3368/le.92.3.491

Nguyen, S., \& Strietwiesser, M. (1997). Capital-energy substitution revisited new evidence from micro data, Center for Economic Studies (CES), Research Paper 97/4.

Özatalay, S., Grubaugh, S., \& Long, T. V. (1979). Energy Substitution and National Energy Policy. The American Economic Review, 69(2), 369-371.

Palivos, T., \& Karagiannis, G. (2010). The Elasticity of Substitution as an Engine of Growth. Macroeconomic Dynamics, 14(5), 617-628. https://doi.org/10.1017/S1365100509000479

Pindyck, R. S. (1979). Interfuel Substitution and the Industrial Demand for Energy: An International Comparison. The Review of Economics and Statistics, 61(2), 169-179.

Revankar, N. S. (1971). A Class of Variable Elasticity of Substitution Production Functions. Econometrica, 39(1), 61-71. https://doi.org/10.2307/1909140

Revankar, N. S. (1971). Capital-Labor Substitution, Technological Change, and Economic Growth: The U.S. Experience, 1929-1953. Metroeconomica, 23(2), 154-176. https://doi.org/10.1111/j.1467-999X.1971. tb00168.x

Stern, D. I. (2011). The Role of Energy in Economic Growth, (SSRN Scholarly Paper No. ID 1878863). Rochester, NY: Social Science Research Network. https://papers.ssrn.com/abstract=1878863

Thompson, P., \& Taylor, T. G. (1995). The Capital-Energy Substitutability Debate: A New Look. The Review of Economics and Statistics, 77(3), 565-569. https://doi.org/10.2307/2109916

Tovar, M. A., \& Iglesias, E. M. (2013). Capital-Energy Relationships: An Analysis when Disaggregating by Industry and Different Types of Capital. The Energy Journal, 34(4), 129-150.

van Zon, A., \& Yetkiner, I. H. (2003). An endogenous growth model with embodied energy-saving technical change. Resource and Energy Economics, 25(1), 81-103. https://doi.org/10.1016/S0928-7655(02)00018-0. 